\title{
IMPLEMENTASI AKAD MUDHARABAH BERDASARKAN PSAK 105 TENTANG AKUNTANSI MUDHRABAH DAN FATWA DSN MUI PADA PRODUK PEMBIAYAAN
}

\author{
Muhammad Fahmul Iltiham \\ Universitas Yudharta Pasuruan \\ fahmul.esy@yudharta.ac.id
}

\begin{abstract}
In a financing transaction that is sacrificed, the Sharia Mudharabah contract is a very familiar transaction agreement for the world of sharia finance today, because the Mudharabah contract itself is a contract of cooperation between the two parties, where one party acts as the owner of capital and the other party acts as the capital manager of a certain business with profit sharing ratio (profit) according to the agreement between the two parties. Because the purpose of this study is to determine the implementation (implementation) of the Mudharabah contract in financing products at Bank Syariah Mandiri KCP Lawang. Then based on the results of the study it is known that the implementation (implementation) of the Mudharabah contract on financing products at Bank Syariah Mandiri KCP Lawang is in accordance with the accounting standards in PSAK 105 on Mudharabah Accounting and also in accordance with sharia reviews based on the DSN MUI Fatwa regarding Mudharabah Financing. The application of the Mudharabah contract at Bank Syariah Mandiri is found in the work shop financing product with the type of working capital financing to customers.
\end{abstract}

Keywords: Mudharabah Agreement, PSAK 105 Mudharabah Accounting, DSN Fatwa, Financing.

\section{PENDAHULUAN}

Bank secara sederhana dapat diartikan sebagai lembaga keuangan yang kegiatan utamanya adalah menghimpun dana masyarakat dan menyalurkannya kembali dana tersebut ke masyarakat serta memberikan jasa bank lainnya. ${ }^{1}$ Bank syariah merupakan bank yang kegiatannya mengacu pada hukum Islam, dan dalam kegiatannya tidak membebankan bunga,

\footnotetext{
${ }^{1}$ Kasmir, Bank dan Lembaga Keuangan Syariah, (Jakarta: PT. Raja Grafindo Persada. Tahun 2001), hlm.11
} 
maupun tidak membayar bunga kepada nasabah. Imbalan yang diterima oleh bank syariah, maupun yang dibayarkan kepada nasabah tersebut didasarkan pada hukum syariah baik perjanjian yang dilakukan bank dengan nasabah dalam penghimpunan dana, maupun penyalurannya. Perjanjian (akad) yang terdapat diperbankan syariah harus tunduk pada syarat dan rukun akad tersebut. $^{2}$

Pembiayaan atau pendanaan yang dilakukan bank syariah kepada nasabah tidak berbeda jauh dengan bank konvensional. Perbedaannya adalah pembiayaan dalam bank syariah tidak didasarkan atas nama produk melainkan berdasarkan prinsip yang digunakan. Salah satu prinsip pembiayaan yang dilakukan oleh bank syariah adalah akad Mudharabah. Akad Mudharabah adalah akad diantara dua belah pihak, dimana pihak yang satu menyerahkan modal dan pihak yang lainnya memberdayakan modal tersebut untuk usaha, serta keuntungan yang diperoleh dibagi bersama dengan porsi bagi hasil disepakati pada saat akad. Pada akad Mudharabah, bank bertindak sebagai pemilik modal (shahibul maal) dan nasabah bertindak sebagai pengelola modal (mudharib) dengan suatu usaha tertentu dan nisbah bagi hasil (keuntungan) sesuai dengan kesepakatan pada saat akad.

Salah satu perbankan syariah yang terkenal dan ternama di Indonesia adalah Bank Syariah Mandiri. Dalam perkembangannya Bank Syariah Mandiri mengalami petumbuhan kinerja yang positif. Hal ini terlihat pada pertumbuhan laba yang telah dicapai oleh Bank Syariah Mandiri yakni sebesar 67\% di Triwulan III tahun 2018. Laba bersih Mandiri Syariah pada triwulan III 2018 mencapai Rp. 435 miliar, naik dibandingkan periode yang sama pada tahun sebelumnya yang sebesar Rp. 261 Miliar. Pertumbuhsn laba tersebut didorong oleh penumbuhan bisnis (pembiayaan dan pendanaan), Fee Based Income, perbaikan kualitas pembiayaan, dan efisiensi biaya. Pembiayaan Mandiri Syariah per Triwulan III 2018 tumbuh sebesar 11,11\%(yoy), semual Rp. 58,72 Triliun pada Triwulan III 2017, menjadi Rp. 65,24 Triliun. Segmen konsumer mencatatkan pertumbuhan tertinggi dengan kenaikan sebesar 28,65 \%(yoy) dari semula Rp. 19,54 Triliun menjadi Rp. 25,14 Triliun. Jika dilihat dari sisi pendanaan. Bank Mandiri Syariah mencatatkan Dana Pihak Ketiga tumbuh 10,07\% dari Rp. 74,75 triliun pada riwulan III 2017 menjadi Rp. 82,28 triliun. Pertumbuhan tersebut terutama

\footnotetext{
${ }^{2}$ Ismail, Manajemen Perbankan Dari Teori Menuju Aplikasi, (Jakarta: Kencana, Tahun 2010), hlm. 20
} 
didorong produk tabungan yang meningkat 13,77\% menjadi Rp. 32,99 triliun per Triwulan III 2018. ${ }^{3}$ Pada produk penghimpunan dana yang ditawarkan, Bank Mandiri Syariah menggunakan prinsip akad wadi'ah dan akad Mudharabah, namun lebih didominasi menggunakan akad Mudharabah. Dana yang diperoleh dari produk penghimpunan dana yang berprinsip akad Mudharabah tersebut kemudian dikelola melalui pembiayaan-pembiayaan kepada nasabah dengan nisbah bagi hasil tertentu sesuai kesepakatan sehingga bisa mendapatkan keuntungan atau laba. Salah satu prinsip pembiayaan yang digunakan oleh Bank Syariah Mandiri juga berdasarkan prinsip akad Mudharabah. Pembiayaan yang dilakukan oleh Bank Syariah Mandiri haruslah sesuai dengan ketentuan syarat, rukun dan tinjauan syariah dari akad Mudharabah tersebut.

\section{KAJIAN TEORI}

\section{Pengertian Akad Mudharabah}

Secara istilah Mudharabah berarti seorang malik atau pemilik modal menyerahkan modal kepada seorang amil untuk berniaga dengan modal tersebu, dimana keuntungan dibagi diantara keduanya dengan porsi bagian sesuai dengan yang dipersyaratkan dalam akad. Dalam Fatawa al Azhar disebutkan bahwa yang dimaksud dengan Mudharabah adalah akad untuk berserikat dalam keuntungan dimana modal dari satu pihak yang berserikat dan pekerjaan dari pihak lain menurut syarat-syarat tertentu. Menurut Sayyid Sabiq, Mudharabah adalah akad dianatara dua belah pihak dimana salah satu pihak menyerahkan modal kepada yang lain untuk berniaga pada modal tersebut dengan keuntungan dibagi diantara keduanya dengan porsi sesuai hasil kesepakatan. ${ }^{4}$

Dari beberapa pengertian tentang Mudharabah diatas, maka dapat dipahami bahwa Mudharabah itu adalah akad diantara dua belah pihak, dimana pihak yang satu menyerahkan modal dan pihak yang lainnya memberdayakan modal tersebut untuk usaha, serta keuntungan yang diperoleh dibagi bersama dengan porsi bagi hasil disepakati pada saat akad. $^{5}$

3 www.syariahmandiri.co.id diakses pada tanggal 10 November 2018.

4 Yadi Janwari, Lembaga Keuangan Syariah, (Bandung: PT. Remaja Rosdakarya, Tahun 2015), hal. 59-60.

${ }^{5}$ Nizar, M, 2015, Strategi Pengembangan Marketing (Studi Kasus di BRPS Adil Makmur Karangploso Malang), MALIA (Terakreditasi), 7 (1). 


\section{Rukun dan Syarat Akad Mudharabah}

Jumhur ulama menyatakan, bahwa rukun Mudharabah terdiri atas orang ynag berakad, modal, keuntungan, kerja, dan akad. Adapun syaratsyarat Mudharabah adalah sebagai berikut: ${ }^{6}$

a. Bagi pihak yang berakad, harus cakap bertindak hukum dan cakap diangkat sebagai wakil (bagi mudharib)

b. Yang terkait dengan modal, disyaratkan: berbentuk uang, jelas jumlahnya, tunai, diserahkan sepenuhnya kepada mudharib

c. Yang terkait dengan keuntungan, disyaratkan bahwa pembagian keuntungan harus jelas dan diambil dari keuntungan.

d. Untuk syarat akad mengikuti syarat sebuah akad pada umumnya, yaitu harus jelas sighatnya dan ada kesesuaian antara ijab dan qabulnya.

\section{Macam-Macam Akad Mudharabah} yaitu: ${ }^{7}$

Ulama Fiqh membagi akad Mudharabah menjadi dua macam

a. Mudharabah Muthlaqah

Mudharabah muthaqah yaitu penyerahan modal secara mutlak tanpa syarat dan pembatasan. Dalam Mudharabah muthaqah, pengusaha bebas mengelola modal dengan jenis usaha apa saja yang menurutnya akan mendatangkan keuntungan dan ditempat mana saja yang dia inginkan.

b. Mudharabah Muqayyadah

Mudharabah muqayyadah yaitu penyerahan modal dengan syarat dan batasan tertentu. Dalam Mudharabah muqayyadah, pengusaha harus mengikuti syarat-syarat dan batasan-batasan yang dibuat oleh pemilik modal.

\section{Standar Akuntansi Akad Mudharabah}

Ketentuan tentang pengukuran dan pengakuan transaksi Mudharabah dalam akuntansi pemilik dana, telah diatur dalam PSAK 105 tentang Akuntansi Mudharabah antara lain sebagai berikut: ${ }^{8}$

${ }^{6}$ Neneng Nurhasanah, Mudharabah dalam Teori dan Prektek, (Bandung: PT. Refika Aditama, Tahun 2015), hal 76.

${ }^{7}$ Ibid, hal 77-78. 
a. Modal Mudharabah

1) Dana Mudharabah yang disalurkan oleh pemilik dana diakui sebagai investasi Mudharabah pada saat pembayaran kas dan penyerahan aset non kas kepada pengelola dana.

2) Pengukuran investasi Mudharabah adalah sebagai berikur:

a) Investasi Mudharabah dalam bentuk kas diukur sebesar jumlah yang dibayarkan.

b) Investasi dalam benruk aset nonkas diukur sebesar nilai wajar aset nonkas pada saat pembayaran:

a) Jika nilai wajar lebih rendah daripada nilai tercatatnya, maka selisihnya diakui sebagai kerugian.

b) Jika nilai wajar lebih tinggi daripada nilai tercatatnya diakui, maka selisi diakuinya sebagai keuntungan tangguhan dan diamortisasi sesuai jangka waktu alad Mudharabah.

3) Jika nilai investasi Mudharabah turun sebelum usaha dimulai disebabkan rusak, hilang atau faktor lain yang bukan kelalaian atau kesalahan pihak pengelola dana, maka penurunan nilai tersebut diakui sebagai kerugian dan mengurangi saldo investasi Mudharabah.

4) Jika sebagian investasi Mudharabah hilai setelah dimulainya usaha tanpa adanya kelalaian atau kesalahan pengelola dan, maka kerugian tersebiut diperhitungkan pada saat bagi hasil.

5) Usaha Mudharabah dianggap mulai berjalan sejak dana atau modal usaha diterima oleh pengelola dana.

6) Dalam investasi Mudharabah yang diberikan dalam bentuk barang (nonkas) dan barang tersebut mengalami penurnan nilai pada saat atau setelah barang dipergunakan secara efektif dalam kegiatan usaha Mudharabah, maka kerugian tersebur tidak langsung mengurangi jumlah investasi, namun diperhitungkan pada saat pembagian hasil.

7) Kelalaian atas kesalahan pengelola dana, antara lain, ditunjukkan oleh:

a) Persyaratan yang ditentukan di dalam akad tidak dipenuhi.

${ }^{8}$ Sofyan S. Harahap, Akuntansi Perbankan Syariah (PSAK Syariah Baru). (Jakarta : Penerbit LPFE Usakti, 2010), hal 295. 
b) Tidak terdapat kondisi diluar kemampuan (force majur) yang lazim dan/atau yang telah ditentukan dalam akad.

c) Hasil keputusan dari institusi yang berwenang.

8) Jika akad Mudharabah berakhir sebelum atau saat akad jatuh tempo dan belum dibayar oleh pengelola dana, maka investasi Mudharabah diakui sebagai piutang.

b. Penghasilan Usaha

1) Jika investasi Mudharabah melebihi satu periode pelaporan, penghasilan usaha diakui dalam periode terjadinya hak bagi hasil sesuai nisab yang disepakati.

2) Kerugian yang terjadi dalam suatu periode sebelum akad Mudharabah berkahir diakui sebagai kerugian dan dibentuk penyisihan kerugian investasi. Pada saat akad Mudharabah berkahir, selisih antara :

a) Investasi Mudharabah setelah dikurangi penyisiha kerugian investasi; dan

b) Pengembalian investasi Mudharabah

3) Pengakuan penghasilan usaha Mudharabah dalam praktik, dapat diketahui berdasarkan laporan bagi hasil atas realisasi penghasilan usaha dari pengelola dana. Tidak diperkenankan mengakui pendapatan dari proyeksi hasil usaha.

4) Kerugian akibat kelalaian atas kesalahan pengelola dana dibebankan pada pengelola dana dan tidak mengurangi investasi Mudharabah.

5) Bagian hasil usaha yang belum dibayar oleh pengelola dana diakui sebagai piutang.

c. Penyajian

1) Pemilik dana menyajikan investasi Mudharabah dalam laporan keuangan sebesar nilai yang tecatat.

2) Pengelola dana menyajikan transaksi Mudharabah dalam laporan keuangan.

a) Dana syrikah temporer dari pemilik dana disajikan sebesar nilai tercatatnya untuk setiap jenis Mudharabah.

b) Bagi hasil dana syirkah temporer yang sudah diperhitungkan dan telah jatuh tempo tetapi belum diserahkan kepada pemilik dana disajikan sebagai kewajiban. 
c) Bagi hasil dana syrikah temporer yang telah diperhitungkan tetapi belum jatuh tempo disajikan dalam pos bagi hasil yang belum dibagikan.

d. Pengungkapan

1) Pemilik dana mengungkapkan hal-hal terkait transaksi Mudharabah, tetapi tidak terbatas pada :

a) Rincian jumlah investasi Mudharabah berdasarkan jenisnya.

b) Penyisihan kerugian investasi Mudharabah selama periode berjalan.

c) Pengungkapan yang diperlukan sesuai PSAK 101; penyajian laporan keuangan syariah.

2) Pengelola dana mengungkapkan hal-hal terkait transaksi Mudharabah, tetapi tidak terbatas pada :

a) Rincian dana syrikah temporer yang diterima berdasarkan jenisnya.

b) Penyaluran dana yang berasal dari Mudharabah muqayyadah.

c) Pengungkapan yang diperlukan sesuai PSAK 101: penyajian laporan keuangan.

\section{Fatwa DSN MUI Tentang Pembiayaan Mudharabah}

Dewan Syariah Nasional menetapkan aturan tentang Pembiayaan Mudharabah sebagaimana tercantum dalam fatwa Dewan Syariah Nasional nomor 07/DSN-MUI/IV/2000 tertanggal 4 April 2000 sebagai berikut $:^{9}$

1. Ketentuan Pembiayaan

a. Pembiayaan Mudharabah adalah pembiayaan yang disalurkan oleh LKS kepada pihak lain untuk suatu usaha yang produktif.

b. Dalam pembiayaan ini LKS sebagai shahibul al-maal (pemilik dana) membiayai $100 \%$ kebutuhan suatu proyek (usaha), sedangkan pengusaha (nasabah) bertindak sebagai mudharib atau pengeloa usaha.

c. Jangka waktu usaha, tata cara pengembalian dana, dan pembagian keuntungan ditentukan berdasarkan kesepakatan kedua belah pihak (LKS dengan pengusaha)

\footnotetext{
${ }^{9}$ Dewan Syariah Nasional MUI, Himpunan Fatwa Keuangan Syariah, (Jakarta: Penerbit Erlangga, 2014), hal 77.
} 
d. Mudharib boleh melakukan berbagai macam usaha yang telah disepakati bersama dan sesuai dengan syariah; dan LKS tidak ikut serta dalam managemen perusahaaan atau proyek tetapi mempunyai hak untuk melakukan pembinaan dan pengawasan.

e. Jumlah dana pembiayaan harus dinyatakan dengan jelas dalam bentuk tunai dan bukan piutamg.

f. LKS sebagai penyedia dana menanggung semua kerugian akibat dari Mudharabah kecuali jika mudharib (nasabah) melakukan kesalahan yang disengaja, lalai, atau menyalahi perjanjian.

g. Pada prinsipnya, dalam pembiayaan Mudharabah tidak ada jaminan, namun agar mudharin tidak melakukan penyimpangan, LKS dapat meminta jaminan dari mudharib atau pihak ketiga. Jaminan ini hanya dapat dicairkan apabia mudharib terbukti melakukan pelanggaran terhadap hal-hal yang telah disepakati bersama dalam akad.

h. Kriteria pengusaha, prosedur pembiayaan, dan mekanisme pembagian keuntungan diatur oleh LKS dengan memperhatikan fatwa DSN-MUI.

i. Dalam hal penyandang dana (LKS) tidak melakukan kewajiban atau melakukan pelanggaran terhadap kesepakatan, mudharib berhak mendapat ganti rugi atau biaya yang telah dikeluarkan.

2. Rukun dan Syarat Pembiayaan

a. Penyedia dana (shahibul maal) dan pengelola harus cakap hukum.

b. Pernyataan ijab dan qabul harus dinyatakan oleh para pihak untuk menunjukkan kehendak mereka dalam mengadakan kontrak (akad), dengan memperhatikan hal-hal berikut:

1) Penawaran dan penerimaan harus secara eksplisit menunjukkan tujuan kontrak (akad).

2) Penerimaan dari penawaran dilakukan pada saar kontrak.

3) Akad dituangkan secara tertulis, melalui korespondensi, atau dengan menggunakan cara-cara komunikasi modern.

c. Modal ialah esjumla uang dan/atau aset yag diberikan oleh penyedia dana kepada mudharib untuk tujuan usaha dengan syarat sebagai berikut :

1) Modal harus diketahui jumlah dan jenisnya. 
2) Modal dapat berbentuk uang atau barang yang dinilai. Jika modal diberikan dalam bentuk aset, maka aset tersebut harus dinilai pada waktu akad.

3) Modal tidak dapat berbentuk piutang dan harus dibayarkan kepada mudharib, baik secara bertahap mauoun tidak, sesuai dengan kespakatan dalam akad.

4) Keuntungan Mudharabah adalah jumlah yang didapat sebagai kelebihan dari modal. Syarat keuntungan berikut ini harus dipernuhi:

a) Harus diperuntukkan bagi kedua belah pihak dan tidak boleh disyaratkan hanya untuk satu pihak.

b) Bagian keuntungan proposional bagi setiap pihak harus diketahui dan dinyatakan pada waktu kontrak disepakati dan harus dalam bentuk prosentasse nisbah dari keuntungan sesuai kesepakatan. Perubahan nisbah harus berdasarkan kesepakatan.

c) Penyedia dana menanggung semua kerugian akibat dari Mudharabah, dan pengelola dana tidak boleh menanggung kerugian apapun kecuali diakibatkan dari kesalahan disengaja, kelalaian, atau pelanggaran kesepakatan.

5) Kegiatan usaha oleh pengelola dana (mudharib), sebagai perimbangan (muqabil) modal yang disediakan oleh pemyedia dana, harus memperimbangkan hal-hal berikut :

a) Kegiatan usaha adalah hak ekskusif mudhsrib, tanpa campur tangan penyedian dana, tetapi ia mempunyai hak untuk melakukan pengawasan.

b) Penyedia dana tidal boleh mempersempit tindakan pengelola sedemikian rupa yang dapat menghalangi tercapainya tujuan Mudharabah yaitu keuntungan.

c) Pengelola dana tidak boleh menyalahi hukum Syariah Islam dalam tindakannya yang berhubungan dengan Mudharabah, dan harus mematuhi kebiasaan yang berlaku dalam akrivitas itu. 
3. Beberapa Ketentuan Hukum Pembiayaan

a. Mudhrabah boleh dibatasi pada periode tertentu.

b. kontrak tidak boleh dikaitkan (mu'allaq) dengan sebuah kejadian di masa depan yang bekum tentu terjadi.

c. Pada dasarnya, dalam Mudharabah tidak ada ganti rugi, karena pada dasarnya akad ini bersifat amanah (yad al-amanah), kecuali akibat dari kesalahan disengaja, kelalaian, atau pelnggaran kesepakatan.

d. Jika salah satu pihak tidak menunaikan kewajiban atau jika terjadi perselisihan di antara kedua belah pihak, maka penyelesaiannya dilakukan melalui Badan Arbitrase Syariah setelah tidak tercapai kesepakatan melalui musyawarah.

\section{METODE}

\section{Jenis Penelitian}

Penelitian ini termasuk penelitian dengan menggunakan motode kualitatif yang bersifat deskriptif. Penelitian kualitatis merupakan metode penelitian yang menggunakan kata-kata, tulisan-tulisan, maupun gambargambar berdasarkan fakta-fakta atau kejadian yang tidak direkayasa sebagai penjelasannya. Dalam penelitian ini penulis menggunakan teknik pengumpulan data melalui observasi, wawancara dan dokumentasi langsung ke lapangan yakni di Bank Syariah Mandiri KCP Lawang.

\section{Sumber Data}

a. Data primer, yaitu data yang dikumpulkan sendiri oleh perseorangan atau organisasi secara langsung melalui objeknya.

b. Data sekunder, yaitu data yang diperoleh dari dokumen, buku-buku dan arsip-arsip yang berkaitan dengan topik data yang akan diteliti dengan metode penulisan kualitatif ini. Sumber data sekunder diperoleh dari buku-buku yang berkaitan dengan judul, mengambil karya atau tugas akhir yang sudah ada sebelumnya dan memiliki tema yang berkaitan, penelitian-penelitiaan yang berkaitan dengan penelitian yang peneliti lakukan, seta dokumen-dokumen yang relevan. 


\section{Analisi Data}

Analisis data merupakan proses penyusunan data secara sisitemastis yang diperoleh dari hasil wawancara, catatan lapangan, dan dokumentasi serta membuat kesimpulan agar dapat difahami dan temuannya dapat diinformasikan kepada orang lain. ${ }^{10}$ Analisis data dalam penelitian ini menggunakan metode analisis deskriptif kualitatif dengan menggambarkan dan menjabarkan secara jelas tentang implementas kesesuaian prakatek transaksi akad Mudharabah berdasarkan PSAK 105 tentang akuntansi Mudharabah dan fatwa DSN MUI pada produk pembiayaan di Bank Syariah Mandiri KCP.Lawang

\section{PEMBAHASAN}

1. Standar Prosedur Operasional Akuntansi Akad Mudharabah Pada Bank Syariah Mandiri

Pengakuan dan Pengukuran Mudharabah

a. Pembiayaan Mudharabah

1) Bank membukukan kewajiban komitmen pada saat memberikan facilility line kepada nasabah dalam Loan Commitment Unused (LCU).

2) Dana Mudharabah yang disalurkan oleh Bank diakui sebagai pembiayaan Mudharabah pada saat pembayaran kas kepada nasabah.

3) Pengukuran pembiayaan Mudharabah dalam bentuk kas diukur ssebesar jumlah yang dibayarkan oleh Bank kepada nasabah.

4) Pembiayaan Mudharabah yang diberikan secara bertahap diakui pada setiap tahap pembayaran.

5) Pembayaran kembali pembiayaan Mudharabah oleh nasabah akan mengurangi pembiayaan Mudharabah.

6) Usaha Mudharabah dianggap mulai berjalan sejak dana atau modal usaha Mudharabah diterima oleh nasabah.

7) Jika akad Mudharabah berakhir sebelum atau saat akad jatuh tempo dan belum dibayar oleh nasabah, maka pembiayaan Mudharabah diakui sebagai piutang.

b. Kerugian akibat kelalaian atau kesalahan nasabah

${ }^{10}$ Sugiyono, Metode Penelitian Kuantitatif dan Kualitatif dan $R \& D$, (Bandung: Alfabeta, 2012), hal 240. 
1) Kerugian akibat kelalaian atau kesalahan nasabah dibebankan pada nasabah dan tidak mengurangi pembiayaan Mudharabah

2) Kelalaian atau kesalahan nasabah antara lain ditunjukkan oleh:

a) Tidak dipenuhinya persyaratan yang ditentukan di dalam akad.

b) Tidak terdapat kondisi di luar kemampuan (force majeur) yang lazim dan/ atau yang telah ditentukan di dalam akad; atau

c) Hasil keputusan dari institusi yang berwenang.

c. Penghasilan usaha Mudharabah (pendapatan bagi hasil)

1) Apabila pembiayaan Mudharabah melebihi satu periode pelaporan, penghasilan usaha diakui dalam periode terjadinya hak bagi hasil sesuai nisbah yang disepakati.

2) Pengakuan penghasilan usaha Mudharabah dalam praktik dapat diketahui berdasarkan laporan bagi hasil atas penghasilan usaha dari nasabah.

3) Bank tidak diperkenankan mengakui pendapatan bagi hasil dari proyeksi hasil usaha.

4) Pendapatan bagi hasil Mudharabah yang telah diterima kasnya merupakan pendapatan Bank yang harus dibagi hasilkan kepada dana pihak ketigaa (tabungan, giro, dan deposito).

5) Pendapatan bagi hasil Mudharabah yang telah dibagihasilkan kepada dana pihak ketiga tidak dapat dikoreksi atau di-reverse kepada nasabah atau pihak lain dalam rangka keperluan tertentu.

d. Piutang atas bagi hasil usaha

1) Bagian hasil usaha yang belum dibayar oleh nasabah diakui sebagai piutang bagi hasil

2) Investasi Mudharabah tidak dapat diakui selesai (lunas) apabila masih terdapat piutang nasabah atas bagian hasil usaha yang belum dibayar oleh nasabah kepada Bank.

3) Bank memiliki hak tagih atas keuntungan/pendapatan bagi hasil Mudharabah yang telah menjadi hak Bank namun belum dibayarkan oleh nasabah. 
e. Potongan atas kewajiban nasabah

Dalam transaksi Mudharabah tidak diakui adanya potongan (pengurangan kewajiban nasabah) untuk: ${ }^{11}$

1) Pelunasan.

2) Potongan atas pengembalian dana investasi yang belum jatuh tempo.

3) Pembayaran hasil usaha porsi Bank yang telah dilaporkan kepada Bank oleh nasabah.

f. Pendapatan dan beban teratribusi

1) Pendapatan dan beban teratribusi tidak dikapitalisasi atai diakui secara terpisah dari investasi Mudharabah sebesar pendapatan yang diterima dan beban yang dikeluarkan.

2) Pendapatan dan beban tertribusi tersebut langsung diakui dalam laporan laba rugi pada saat pemdapatan diterima dan beban dikeluarkan.

3) Pendapatan teratribusi merupakan bagian dari fee based income yang tidak dibagihasilkan kepada dana pihak ketiga (tabungan, giro, dan deposito).

g. Hal-hal yang tidak terbatas terkait transaksi Mudharabah

Bank mengungkapkan hal-hal terkait transaksi Mudharabah, tetapi tidak terbatas pada :

1) Rincian jumlah pembiayaan Mudharabah berdasarkan sifat akad (Mudharabah mutlaqah dan Mudharabah muqayyadah), jenis penggunaan dan sektor ekonomi.

2) Klasifikasi pembiayaan Mudharabah menurut jangka waktu (masa akad), kualitas pembiayaan, valuta, cadangan penyisihan kerugian pembiayaan dan tingkat bagi hasil rata-rata.

3) Jumlah dan persentase pembiayaan Mudharabah yang diberikan kepada pihak-pihak berelasi.

4) Jumlah pembiayaan Mudharabah yang telah direstrukturisasai dan informasi lain tentang pembiayaan Mudharabah yang direstrukturisasi selama periode berjalan.

11 Nizar, M, 2016, Pengaruh Pembiayaan Mudharabah Terhadap Peningkatkan Kesejahteraan Pelaku UMKM (studi kasus BMT Maslahah Capang Pandaan), MALIA (Terakreditasi), 7 (2), 287-310. 
5) Kebijakan manajemendalam pelaksanaan pengendalian risiko portofolio pembiayaan Mudharabah.

6) Besarnya pembiayaan Mudharabah bermasalah dari cadangan penyisihan kerugian piutang untuk setiap sektor ekonomi.

7) Kebijakan dan metode yang dipergunakan dalam penanganan Mudharabah bermasalah.

8) Ikhitsar pembiayaan Mudharabah yang dihapus buku yang menunjukkan saldo awal, penghapusan selama tahun berjalan, penerimaan, atas pembiayaan Mudharabah yang telah dihapusbukukan dan pembiayaan Mudharabah yang telah dihapus tagih dan saldo akhir pembiayaan Mudharabah yang dihapus buku.

h. Penyajian Mudharabah

1) Pembiayaan Mudharabah disajikan sebesar saldo pembiayaan Mudharabah nasabah kepada Bank.

2) Piutang bagi hasil disajikan sebagai bagian dari aset lain pada saat nasabah tergolong performing. Sedangkan, apabila nasabah tergolong non-performing maka piutang bagi hasil disajikan pada rekening administratif.

3) Cadangan PPAP Mudharabah disajikan sebagai pos lawan (contra account) pembiayaan Mudharabah.

4) Pembiayaan Mudharabah yang diakhiri sebelum jatuh tempo atau sudah berakhir dan belum diselesaikan oleh nasabah disajikan terpisah dengan pembiayaan Mudharabah menjadi piutang Mudharabah.

i. Penghasilan Usaha Mudharabah (pendapatan bagi hasil)

1) Bank tidak diperkenankan melakukan pembukuan (pelaporan) pada sistem atas penghasilan usaha Mudharabah nasabah berdasarkan proyeksi pendapatan bagi hasil yang ditentukan di awal akad, namun benar-benar berdasarkan realisasi penghasilan usaha yang dilaporkan oleh nasabah yang terdokumentasi (seperti laporan keuangan nasabah, laporan realisasi penjualan nasabah, surat kesanggupan bayar dari nasabah, dll).

2) Bank wajib melakukan penagihan atas realisasi penghasilan usaha porsi Bank yang dilaporkan dan telah dibuku pada sistem. 
3) Bank tidak diperkenankan melakukan potongan kewajiban nasabah atas realisasi penghasilan usaha porsi Bank yang dilaporkan dan telah dibuku pada sistem.

j. Pembagian hasil usaha

Bank melakukan pembagian hasil usaha Mudharabah berdasarkan total pendapatan usaha (omset) nasabah (revenue sharing methode) dengan mempertimbangkan hal-hal sebagai berikut :

1) Bank membutuhkan kompetensi SDM dalam penguasaan metode pengalokasian biaya harga perolehan persediaan sehingga bank mengalami penambahan pekerjaan klerikal yang mengakibatkan inefiensi kerja dan disintensif bagi kegiatan usaha UMKM.

2) Bank harus memenuhi sejumlah persyaratan agar tidak terjadi akses informasi yang tidak seimbang (asymetricinformation), adevrse selection, dan moral hazard diantara para pihak.

3) Memperbesar resiko, waktu yang dibutuhkan dan ongkos sehingga akan menurunkan kemampuan bank syariah dalam berkompetisi dalam industri perbankan.

k. Pembukuan Manual Transaksi Mudharabah

1) Pada saar Bank memberikan facility line pada nasabah

Db. Kontra Loan Commitment Unused

$\operatorname{xxxxx}$

Kr. Loan Commitment Unused

$\mathrm{xxxxx}$

(LCU tersebut akan di-reserve pada saat pembiayaan tersebut dicairkan).

2) Pada saat Bank melakukan pencairan kepada nasabah

Db. Pembiayaan Mudharabah

$\operatorname{xxxxx}$

Kr. Rekening nasabah

$\operatorname{xxxxx}$

3) Pada saat nasabah melaporkan pendapatan porsi (hak) Bank atas bagi hasil usahanya

Db. Pend. Bagi Hasil Mudharabah yang akan diterima xxxxx

Kr. Pendapatan Bagi Hasil Mudharabah Akrual xxxxx

Bank telah mengakui pendapatan atas bagi hasil usaha yang dilaporkan oleh nasabah.

4) Pada saat nasabah membayar angsuran pokok pembiayaan Mudharabah

Db. Rekening nasabah

$\operatorname{Xxxxx}$ 


\section{Kr. Pembiayaan Mudharabah xxxxx}

5) Pada saat nasabah membayar pendapatan porsi (hak) Bank atas hasil usahanya yang telah dilaporkan

Db. Rekening Xxxxx

Kr. Pend. Bagi Hasil Mudharabah yang akan diterima xxxxx

Db. Pend. Bagi Hasil Mudharabah Akrual Xxxxx

Kr. Pend. Bagi Hasil Mudharabah Kas

$\operatorname{XXXXX}$

\section{Tinjauan Syariah Akad Mudharabah}

Berdasarkan hasil wawancara dan pengamatan selama kegiatan magang di Bank Syariah Mandiri KCP Lawang, secara garis besar pelaksanaan akad Mudharabah sudah sesuai dengan tinjauan syariah yang pada penelitian ini berdasarkan pada Fatwa DSN MUI tentang Pembiayaan Mudharabah karena semua pembuatan standar prosedur operasional pembiayaan Mudharabah di Bank Syariah Mandiri didasarkan pada Fatwa DSN MUI dan peraturan Bank Indonesia.

Pihak Bank Syariah Mandiri KCP Lawang bertindak sebagai pemilik dana (shahibul maal) dan nasabah bertindak sebagai pengelola dana (mudhraib) dalam pembiayaan Mudharabah baik bersifat muthlaqah maupun muqayyadah tetapi dalam prakteknya lebih didominasi bersifat muthlaqah. Dimana nasabah pembiayaan Mudharabah boleh melakukan berbagai macam usaha yang telah disepakati bersama dan sesuai dengan syariah. Bank Syariah Mandiri tidak ikut serta dalam manajemen pengelolaan usaha tersebut namung berhak untuk melakukan pembinaan dan pengawasan. Namun, jika pembiayaan Mudharabah bersifat muqayyadah ada beberapa beberapa batasan-batasan tertentu yang tertera pada standar prosedur operasional akad Mudharabah diantaranya:

a. Nasabah tidak mencampurkan dana Bank dengan dana lainnya.

b. Nasabah tidak menginvestasikan dananya pada transaksi penjualan cicilan, tanpa penjamin, atau tanpa jaminan.

c. Mengharuskan nasabah untuk melakukan investasi tanpa melalui pihak ketiga. 
Jangka waktu usaha (periode pelaksanaan akad pembiayaan mudhrabah), tata cara pengembalian dana dan pembagian keuntungan ditentukan berdasarkan kesepakatan antara bank dengan nasabah. Pengembalian dana mudhrabah dapat dilakukan secara bertahap bersamaan dengab distribusi bagi hasil atau secara total pada saat akad Mudharabah diakhiri. Jika dari pengelolaan dana midharabah menghasilkan keuntungan, maka porsi jumlah bagi hasil untuk Bank dan nasabah ditentukan berdasarkan nisbah yang disepakati dari hasil usaha yang diperoleh selama periode akad. Jika dari pengelolaan dana Mudharabah menimbulkan kerugian, maka kerugian finansial menjadi tanggung jawab Bank.

Pembagian hasil usaha Mudharabah dapat dilakukan berdasarkan total pendapatan usaha (omset), prinsip bagi hasil, dan atau bagi laba. Jika berdasarkan prinsip bagi hasil, maka dasar pembagian hasil usaha adalah laba bruto (gross profit margin). Sedangkan jika berdasarkan prinsip bagi laba, dasar pembagian hasil usaha adalah laba neto (net profit( yaitu laba bruto dikurangi beban yang berkaitan dengan pengelolaan dana Mudharabah.

Pelaksanaan ijab dan qabul akad Mudharabah antara Bank Syariah Mandiri dan nasabah dihadiri juga oleh pihak notaris sebagai saksi dan pengikat dengan SKMHT (Surat Kuasa Membebankan Hak Tanggungan) atau APHT (Akta Pengikatan Hak Tanggungan). Selain itu segala ketentuan-ketentuan yang telah disepakati diantara kedua belah pihak (Bank dengan nasabah) dalam akad Mudharabah tersebut dituangkan secara tertulis yang bertanda tangan diatas materai dan dibacakan oleh notaris pada saat akad Mudharabah dilaksanakan.

Bank Syariah Mandiri KCP Lawang juga meminta jaminan kepada nasabah atas akad Mudharabah seperti Sertifikat Hak Milik, Letter C ataupun BPKB Mobil agar mudharib (nasabah) tidak melakukan penyimpangan. Jaminan tersebut hanya dapat dicairkan apabila mudharib terbukti melakukan pelanggaran terhadap hal-hal yang telah disepakati bersama. Limit pembiayaan yang dapat diberikan oleh Bank Syariah Mandiri dengan beberapa jenis jaminan tersebut adalah sekitar antara sekitar 11 juta sampai 200 juta. 


\section{KESIMPULAN}

Berdasarkan hasil pembahasan di atas dapat disimpulkan bahwa penerapan akad Mudharabah di Bank Syariah Mandiri KCP Lawang :

1. Terdapat pada produk pembiayaan warung mikro dengan fitur pembiayaan modal kerja dan limit pembiayaan berkisar antara 11 juta sampai 200 juta.

2. Penerapan akad Mudharabah di Bank Syariah Mandiri telah sesuai dengan standar akuntansi akad Mudharabah yang tertuang pada PSAK 105 tentang Akuntansi Mudharabah dan juga telah sesuai dengan ketentuan Fatwa DSN MUI tentang Pembiayaan Mudharabah.

\section{DAFTAR PUSTAKA}

Dewan Syariah Nasional MUI, 2014, Himpunan Fatwa Keuangan Syariah, Jakarta: Penerbit Erlangga.

Harahap, Sofyan S, 2010, Akuntansi Perbankan Syariah (PSAK Syariah Baru). Jakarta: Penerbit LPFE Usakti.

Ismail, 2010, Manajemen Perbankan Dari Teori Menuju Aplikasi, Jakarta: Kencana.

Janwari, Yadi, 2015, Lembaga Keuangan Syariah, Bandung: PT. Remaja Rosdakarya.

Kasmir, 2001, Bank dan Lembaga Keuangan Syariah, Jakarta: PT. Raja Grafindo Persada.

Nizar, M, 2015, Strategi Pengembangan Marketing (Studi Kasus di BRPS Adil Makmur Karangploso Malang), MALIA (Terakreditasi), 7 (1).

Nizar, M, 2016, Pengaruh Pembiayaan Mudharabah Terhadap Peningkatkan

Kesejahteraan Pelaku UMKM (studi kasus BMT Maslahah Capang Pandaan), MALIA (Terakreditasi), 7 (2), 287-310.

Nurhasanah, Neneng, 2015, Mudharabah dalam Teori dan Prektek, Bandung: PT. Refika Aditama.

Sugiyono, Metode Penelitian Kuantitatif dan Kualitatif dan $R \& D$, Bandung: Alfabeta, 2012. www.syariahmandiri.co.id diakses pada tanggal 10 November 2018. 